\title{
Fe-Catalyzed reactions of 2-chloro-1,7-dienes and allylmalonates
}

\author{
David Nečas $^{a}$, Pavel Drabina ${ }^{b}$, Miloš Sedlák $^{b}$ and Martin Kotora ${ }^{a, c}$ \\ ${ }^{a}$ Department of Organic and Nuclear Chemistry, and Center for Structural and Synthetic Application of Transition \\ Metal Complexes, Faculty of Science, Charles University, Hlavova 8, 12843 Prague 2, Czech Republic \\ ${ }^{\mathrm{b} D e p a r t m e n t}$ of Organic Chemistry, Faculty of Chemical Technology, University of Pardubice, Nám. Čes. Legií \\ 565, 53210 Pardubice, Czech Republic
}

${ }^{\mathrm{c} I n s t i t u t e}$ of Organic Chemistry and Biochemistry, Academy of Sciences of the Czech Republic, Flemingovo náměstí 2, 16610 Prague 6, Czech Republic

\begin{abstract}
$\mathrm{Fe}(\mathrm{III})(\mathrm{BIAP}) \mathrm{Cl}_{3}$ complex catalyzes alkylative cyclization of 2-chloro-1,7-heptadiene in the presence of triethylaluminum. It also catalyzes deallylation of certain 2-allyl-2-substituted malonates under the same reaction conditions.
\end{abstract}

\section{Graphical abstract}

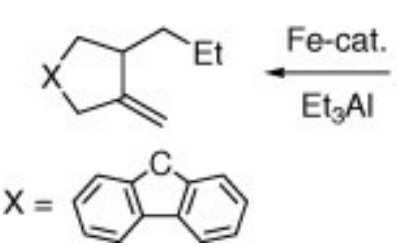<smiles>[X]C(=O)OCCC(=C)Cl</smiles>

Although iron is one of the most abundant metals found in nature, the use of its compounds as catalysts for the formation of $\mathrm{C}-\mathrm{C}$ bonds in organic synthesis is rather limited, especially in comparison with other transition metals $(\mathrm{Ni}, \mathrm{Pd}, \mathrm{Rh}$, etc.). Problems associated with the use of the iron compounds as the catalysts often stem from the fact that the catalytically active species are sensitive to reaction conditions used and often lack generality with respect to the structure of reactants. On the other hand, iron compounds are able to catalyze a plethora of interesting transformations, ${ }^{1}$ and are thus attractive targets for further research. In iron-catalyzed cross-coupling reactions, for example, after pioneering work by Kochi in the early $1970 \mathrm{~s}^{2}{ }^{2}$ iron catalyzed processes made a comeback in the work of Fürstner and Knochel, who showed its generality. ${ }^{[3] \text { and }[4]}$ We have recently reported a new process: an alkylative cyclization of 2-chloro-1,7-dienes in the presence of a catalytic amount of a Fe-phosphine complex and trialkylaluminums. The main feature of this reaction was an unprecedented iron-catalyzed alkyl group (Et, Me) transfer from the trialkylaluminum to the cyclized products. ${ }^{5}$ In addition we observed that under the same reaction conditions certain allylmalonate substrates underwent deallylation. The latter process was later shown to proceed also under $\mathrm{Ni}^{6}$ and $\mathrm{Rh}^{-}$catalyses.

Because of our interest in the development of new Fe-catalyzed reactions, we decided to search for a better ironbased catalytic system, especially because Fe-phosphine complexes lack generality with respect to the substrate. We envisioned that a change of the phosphorus-based ligand for a nitrogen-based one (BIAP = bis(imidazolonyl)pyridine) could result in the formation of more powerful catalysts. This assumption was based on 
the results obtained during Rh-catalyzed deallylations, in which it was clearly demonstrated that the BIAP ligated complexes are more catalytically active then those with phosphines. ${ }^{7}$

At the outset, the starting $\mathrm{Fe}(\mathrm{III})(\mathrm{BIAP}) \mathrm{Cl}_{3}$ 1a-e complexes were prepared according to the previously reported procedure (Fig. 1). ${ }^{8}$ As a test reaction we chose alkylative cyclization of 9-allyl-9-(2-choroallyl)-9H-fluorene 2 . The reaction was carried out under standard conditions. ${ }^{9}$ The results obtained are presented in Table 1 . In all cases the reaction was almost complete within $1 \mathrm{~h}$ and prolonging the reaction time to $24 \mathrm{~h}$ did not result in substantial improvement in the yield of the cyclized product 3 . This is in sharp contrast with Fe-phosphine catalysts, where the yield gradually increased with the reaction time. As for the catalytic activity, the best yield of $\mathbf{3}$ was obtained with catalyst 1a. It was slightly higher when $15 \mathrm{~mol} \%$ of $\mathbf{1 a}$ was used (see Table 2).

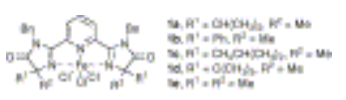

Figure 1. $\mathrm{Fe}(\mathrm{III})(\mathrm{BIAP}) \mathrm{Cl}_{3}$ complexes 1a-e.

Table 1.

Alkylative cyclization catalyzed by $1 \mathbf{a}-\mathbf{e}^{a}$

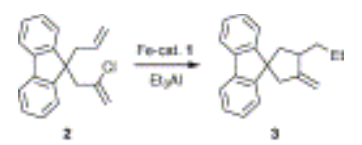

\begin{tabular}{|l|l|l|}
\hline Catalyst 1 & $\boldsymbol{t}(\mathbf{h})$ & $\mathbf{3}$ Yield $^{\mathbf{b}} \mathbf{( \% )}$ \\
\hline $\mathbf{1 a}$ & 1 & $35(53)^{\mathbf{c}}$ \\
\hline & 24 & $48(61)^{\mathrm{C}}$ \\
\hline $\mathbf{1 b}$ & 1 & 11 \\
\hline & 24 & 27 \\
\hline $\mathbf{1 c}$ & 1 & 26 \\
\hline & 24 & 38 \\
\hline $\mathbf{1 d}$ & 1 & 30 \\
\hline & 24 & 38 \\
\hline \hline $\mathbf{1 e}$ & 1 & 26 \\
\hline & 24 & 36 \\
\hline
\end{tabular}

$5 \mathrm{~mol} \%$ of the catalyst.

${ }^{\mathrm{b}} \mathrm{GC}$ yields.

${ }^{c} 15 \mathrm{~mol} \%$ of the catalyst. 
Table 2.

Deallylation catalyzed by $\mathrm{Fe}(\mathrm{III})(\mathrm{BIAP}) \mathrm{Cl}_{3}$ complex $1 \mathrm{a}^{\mathrm{a}}$

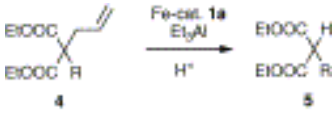

\begin{tabular}{|c|c|c|}
\hline Malonate 4 & $\mathbf{R}$ & 5 , Yield ${ }^{\mathrm{D}}(\%)$ \\
\hline $4 a$ & & $5 a, 13$ \\
\hline $4 b$ & & $5 b, 26$ \\
\hline $4 c$ & & $5 c, 83(48)^{\mathrm{c}}$ \\
\hline $4 d$ & & $5 d, 59(45)^{c}$ \\
\hline $4 e$ & & $5 e, 38$ \\
\hline $4 f$ & & 5f, 91 \\
\hline
\end{tabular}

$5 \mathrm{~mol} \% ; \mathrm{Et}_{3} \mathrm{Al}, 200 \mathrm{~mol} \%, 20^{\circ} \mathrm{C}, 24 \mathrm{~h}$.

b ${ }^{1} \mathrm{H}$ NMR yields.

c $1 \mathrm{~h}$.

Next we turned our attention to the deallylation reaction, because in our previous experiments the Fe-phosphine complex catalyzed the reaction only with allyl(chloroallyl)malonate $4 c .{ }^{5}$ Catalyst 1 a was used because it had proved to be the most active catalyst in the alkylative cyclization, and reactions were carried out under standard conditions. ${ }^{10}$ The deallylation of diallylmalonate 4 a proceeded with low conversion giving only a low yield (13\%) of allylmalonate $\mathbf{5 a}$ together with recovered starting material. Similarly allyl(methallyl)malonate $\mathbf{4 b}$ was deallylated and also in low yield giving only $26 \%$ of methallylmalonate $\mathbf{5 b}$. On the other hand, the deallylation of allyl(chloroallyl)malonate $4 \mathrm{c}$ gave rise to the deallylated product, (chloroallyl)malonate 5c, in high $83 \%$ yield (48\% after $1 \mathrm{~h}$ ). Also, the deallylation of butyl(allyl)malonate $\mathbf{4 d}$ proceeded to a reasonable extent: butylmalonate $\mathbf{5 d}$ was formed in $59 \%$ yield ( $45 \%$ in $1 \mathrm{~h}$ ). The efficiency of deallylation fell again in the case of allylbenzylmalonate $4 \mathbf{e}$, which gave only $38 \%$ of $\mathbf{5 e}$. Surprisingly, almost quantative deallylation was observed for allylphenylmalonate 4f: $\mathbf{9 1 \%}$ of $\mathbf{5 f}$. Attempts to deallylate diallylcoumaranone failed completely, the starting material remaining intact. In summary, we have shown that Fe(III)-BIAP complexes 1 can catalyzed alkylative cyclization, the catalytic activity of $1 \mathrm{a}$ being close to that of Fe-phosphine complexes. ${ }^{5}$ As for the deallylation, the reactions carried out in the presence of 1a gave better results than Fe-phosphine complexes. Nonetheless, the results again showed that the course of the reaction is highly dependent on the structure of substrates and is rather unpredictable. The scope of the reaction with respect to other substrates as well as further elaboration of the ligand structure is under investigation. Spectral characteristics $\left({ }^{1} \mathrm{H}\right.$ and ${ }^{13} \mathrm{C}$ NMR) of all formed compounds were in agreement with the previously published data. ${ }^{[6]}$ and [7]

\section{Acknowledgements}


We gratefully acknowledge financial support by the Ministry of Education of the Czech Republic to the Center for Structural and Synthetic Application of Transition Metal Complexes (Project No. LC06070), the Project MSM 002 162 7501, and the Project MSM 0021620857.

\section{References and notes}

1 (a)For reviews, see: C. Bolm, J. Legros, J. Le Paih and L. Zani, Chem. Rev. 104 (2004), pp. 6217-6254.

(b)A. Fürstner and R. Martin, Chem. Lett. 34 (2004), pp. 624-629.

(c)D. Nečas and M. Kotora, Chem. Listy 100 (2006), pp. 967-973.

2 (a)M. Tamura and J.K. Kochi, J. Am. Chem. Soc. 93 (1971), pp. 1487-1489.

(b)M. Tamura and J.K. Kochi, Bull. Chem. Soc. Jpn. 44 (1971), pp. 3063-3073.

(c)M. Tamura and J.K. Kochi, Synthesis (1971), pp. 303-305.

(d)J.K. Kochi, Acc. Chem. Res. 7 (1974), pp. 351-360.

3 (a)A. Fürstner and A. Leitner, Angew. Chem., Int. Ed. 41 (2002), pp. 609-612.

(b)A. Fürstner, A. Leitner, M. Méndez and H. Krause, J. Am. Chem. Soc. 124 (2002), pp. 13856-13863.

(c)B. Scheiper, M. Bonnenkessel, H. Krause and A. Fürstner, J. Org. Chem. 69 (2004), pp. 3943-3949.

4 (a)W. Dohle, F. Kopp, G. Cahiez and P. Knochel, Synlett (2001), pp. 1901-1904.

(b)C. Duplais, F. Bures, I. Sapountzis, T.J. Korn, G. Cahiez and P. Knochel, Angew. Chem., Int. Ed. 43 (2004), pp. 2968-2970.

(c)I. Sapountzis, W.W. Lin, C.C. Kofink, C. Despotopoulou and P. Knochel, Angew. Chem., Int. Ed. 44 (2005), pp. 1654-1658.

(d)G. Dunet and P. Knochel, Synlett (2006), pp. 407-410.

(e) Lyle, F. R. U.S. Patent 5973 257, 1985; Chem. Abstr., 1985, 65, 2870.

5 D. Nečas, M. Kotora and I. Císařová, Eur. J. Org. Chem. (2004), pp. 1280-1285.

6 (a)D. Nečas, M. Turský and M. Kotora, J. Am. Chem. Soc. 126 (2004), pp. 10222-10223.

(b)D. Nečas, M. Turský, I. Tišlerová and M. Kotora, New J. Chem. 30 (2006), pp. 671-674.

7 M. Turský, D. Nečas, P. Drabina, M. Sedlák and M. Kotora, Organometallics 25 (2006), pp. 901-907.

8 M. Sedlák, P. Drabina, I. Císařová, A. Růžička, J. Hanusek and V. Macháček, Tetrahedron Lett. 45 (2004), pp. 7723-7726.

9 A typical experimental procedure for alkylative cyclization. To a solution of $2(0.5 \mathrm{mmol}, 140 \mathrm{mg})$ and Fe-BIAP complex $1 \mathrm{a}(0.025 \mathrm{mmol}, 18 \mathrm{mg})$ in dry toluene $(3 \mathrm{ml})$ under argon was added $\mathrm{Et}_{3} \mathrm{Al}$ solution in toluene $(2 \mathrm{M}$, $1 \mathrm{mmol}, 0.5 \mathrm{ml}$ ). The reaction mixture was stirred under argon for $24 \mathrm{~h}$ at $20^{\circ} \mathrm{C}$. After that it was quenched with water $(1 \mathrm{ml})$ followed by $3 \mathrm{M}$ solution of $\mathrm{HCl}(3 \mathrm{ml})$. The organic layer was separated and dried $\left(\mathrm{MgSO}_{4}\right)$. Then the reaction mixture was analyzed by ${ }^{1} \mathrm{H}$ NMR.

10 A typical experimental procedure for deallylation reaction. To a solution of $4(0.5 \mathrm{mmol}, 140 \mathrm{mg})$ and Fe-BIAP complex $1 \mathrm{a}(0.025 \mathrm{mmol}, 18 \mathrm{mg})$ in dry toluene $(3 \mathrm{ml})$ under argon was added $\mathrm{Et}_{3} \mathrm{Al}$ solution in toluene $(2 \mathrm{M}$, $1 \mathrm{mmol}, 0.5 \mathrm{ml}$ ). The reaction mixture was stirred under argon for $24 \mathrm{~h}$ at $20^{\circ} \mathrm{C}$. After that it was quenched with 
water $(1 \mathrm{ml})$ followed by $3 \mathrm{M}$ solution of $\mathrm{HCl}(3 \mathrm{ml})$. The organic layer was separated and dried $\left(\mathrm{MgSO}_{4}\right)$. Then the reaction mixture was analyzed by ${ }^{1} \mathrm{H}$ NMR. 